\title{
Critical Level of Manganese in Soil and Leaves: It's Relationship to Fruit Quality of Mangosteen (Garcinia mangostana L.)
}

\author{
Martias $^{1}$, Bambang Hariyanto ${ }^{1}$, Titin Purnama ${ }^{1}$, Nofiarli ${ }^{1}$, Deni Emilda ${ }^{1}$, Hendri ${ }^{1}$, \\ Adha Fatmah Siregar ${ }^{2}$, A. Kasno ${ }^{2}$, Sri Yuliati ${ }^{1}$, Desi Hernita ${ }^{3}$, \\ I. Gusti K. D. Arsana ${ }^{4}$ and Made J. Mejaya ${ }^{5^{*}}$ \\ ${ }^{1}$ Indonesian Tropical Fruit Research Institute, West Sumatera, Indonesia. \\ ${ }^{2}$ Indonesian Agency for Agricultural Research and Developmen, Jakarta, Indonesia. \\ ${ }^{3}$ Institute for Agricultural Technology, Jambi, Indonesia. \\ ${ }^{4}$ Institute for Agricultural Technology, Bali, Indonesia. \\ ${ }^{5}$ Indonesian Legumes and Tuber Crops Research Institute (ILETRI), East Java, Indonesia.
}

Authors' contributions

This work was carried out in collaboration among all authors. All authors read and approved the final manuscript.

Article Information

DOI: $10.9734 / A R R B / 2021 / v 36 i 930427$

Editor(s):

(1) Prof. Ibrahim Farah, Jackson State University, USA.

Reviewers:

(1) Sutrisno Mardjan, IPB University, Indonesia.

(2) Benjapon Kunlanit, Mahasarakham University, Thailand.

Complete Peer review History: https://www.sdiarticle4.com/review-history/74066

Original Research Article

Received 12 July 2021

Accepted 22 September 2021

Published 27 September 2021

\begin{abstract}
Manganese $(\mathrm{Mn})$ is one of the essential micronutrients that plays a crucial role in plants' growth and development and is also considered a limiting factor for crop production. This study aimed to determine the critical level of $\mathrm{Mn}$ in soil and leaves for improving the quality of mangosteen fruit. The research was conducted in 2015 in several mangosteen production centers, including West Sumatra (Simalanggang and Banja Laweh), West Java (Karacak and Barengkok), Bali (Belimbing and Selamadeg). A well-maintained of fifteen to twenty years old mangosteen plants were used with uniform soil fertility. Purposive random sampling is conducted in each location to select ten plants from each site. Soil samples are taken from under the plant canopy around 0-30 $\mathrm{cm}$ in depth at the four cardinal directions. The terminal leaves that collected from the middle part of the plant canopy are used as the leaf samples. Physiological ripe fruits are taken after ripening with index 3-4.
\end{abstract}


The parameters observed consist of (1) soil $\mathrm{pH}$ of $\mathrm{H}_{2} \mathrm{O}, \mathrm{Ca}, \mathrm{Mg}, \mathrm{Mn}$-available, (2) levels of $\mathrm{Mn}, \mathrm{Ca}$, $\mathrm{Mg}$, and $\mathrm{K}$ in the leaves, (3) fruit quality (fruit weight, fruit diameter, fruit skin thickness, aryl weight, seed weight). The results showed the $\mathrm{Mn}$ content in the soil ranged from 18.89 to $33.63 \mathrm{ppm}$. Available $\mathrm{Mn}$ is negatively affected by $\mathrm{pH}, \mathrm{Ca}$, and $\mathrm{Mg}$ exchangeability. Soil $\mathrm{Mn}$ is linearly related to leaf $\mathrm{Mn}$ with $\mathrm{R}^{2} 0.76$. The critical values of $\mathrm{Mn}$ in leaf and soil for mangosteen plants in Indonesia were $425 \mathrm{ppm}$ and 22 to $24 \mathrm{ppm}$, respectively.

Keywords: Critical level; manganese; mangosteen; fruit; soil.

\section{INTRODUCTION}

Mangosteen (Garcinia mangostana L.) has been developed in several sub-optimal lands in Indonesia. This sub-optimal land is dominated by acid soil, which is characterized by macronutrients deficiency and excessive micronutrients, predominantly $\mathrm{Mn}$. An excessive amount of Mn could suppress the availability of $\mathrm{Ca}$ and $\mathrm{Mg}$ for plants and decrease fruit quality. Manganese $(\mathrm{Mn})$ is considered a limiting factor for crop production on acid soils and also could interfere in neutral or alkaline soils with poor aeration [1]. As the $\mathrm{pH}$ decreases, $\mathrm{Mn}$ is mobilized from various forms and increases $\mathrm{Mn}$ concentration in soil solution and its availability. At low soil $\mathrm{pH}(<5.2)$, mostly $\mathrm{Mn}$ was in an available form for plant uptake which is influenced by plant roots [2].

As an essential micronutrient, Mn plays a crucial role in plants' growth and development and contributes to the structure of proteins and enzymes in photosynthesis. Deficiency $\mathrm{Mn}$ is harmful to chloroplasts because it affects the water separation system in photosynthesis II (PS II), providing the necessary electrons in photosynthesis. Despite the importance of $\mathrm{Mn}$ on photosynthesis and other processes, the physiological relevance of $\mathrm{Mn}$ uptake and compartmentation in plants has been underrated $[3,4]$. Mn deficiency leads to the reduced number of Mn-complexes in PSII cores, leading to destabilization and disintegration of PSII complexes that decrease the clean photosynthesis rate [5]. However, most studies showed a decline in photochemical activity, in particular, that of PSII upon Mn limitation [6]. The result of omission macro and micronutrients for deficiencies in mangosteen leaves show that $\mathrm{Mn}$ is deficient if give at 17 and $58 \mathrm{mg} \mathrm{Mn} \mathrm{kg}$ [7].

Manganese is easily absorbed by roots in the form of $\mathrm{Mn}^{2+}$ and accumulated in plant tissues. However, under exceeded concentration, it tends to be toxic for plant growth and development [8].
Manganese toxicity is one of the most important interferes to plant growth on acid soils. Excessive $\mathrm{Mn}$ can prevent the absorption and translocation of other essential elements such as $\mathrm{Ca}, \mathrm{Mg}, \mathrm{Fe}$, and $P \quad[9,10,11]$ and inhibits chlorophyll biosynthesis [12]. Mn toxicity involves a decline in photosynthetic efficiency, a reduction of respiration, and decreased photosynthetic pigment content as physiological effects and tends to increase $\mathrm{Mn}$ oxidized and phenolic substance in the apoplast $[13,14]$. Accumulation of excess $\mathrm{Mn}$ in the leaves, its primary sequestration in the photosynthetic tissues, and multiple-layer palisade mesophyll [15].

Recently, the indication of excessive $\mathrm{Mn}$ absorptions in several mangosteen production centers has been noticed. A strong indicator revealed that high variation levels of $M n$ concentration in soils and plant tissues lead to varied the quality of mangosteen fruit. However, it is not yet well-known the sufficient amount of $\mathrm{Mn}$ concentration in the soil and the leaves that are required to produce a good quality of the mangosteen fruit. The research to establish the critical level of $\mathrm{Mn}$ and its relation to the quality of the mangosteen fruit is required to be conducted. This study aimed to determine the critical limit of $\mathrm{Mn}$ and its relationship to fruit quality and leaf nutrient content in several mangosteen production centers in Indonesia.

\section{METHODOLOGY}

\subsection{Place and Time of Study}

The research was conducted in 2015 in three Provinces of mangosteen production centers namely: West Sumatra Province (three locations: Simalanggang, Banja Laweh, and experimental station of Tropical Fruit Research Institute in Solok), West Java Province (two locations: Karacak and Barengkok), and Bali Province (two locations: Belimbing and Salamadeg). 
Fifteen to twenty years old of mangosteen plants with uniform soil fertility status was used. These research sites were selected based on the production potential area, and collecting traders at the district and sub-district levels. Purposive random sampling is arranged in each location of the research. Ten plants samples were selected and 100 fruits with physiological maturity at stage 2 [16] were harvested from each plant sample for fruit quality analysis. Fully developed leaf samples were collected from the terminal branch for nutrients analysis.

Parameters observed included soil chemical properties $\left(\mathrm{pH} \mathrm{H} \mathrm{H}_{2} \mathrm{O}, \mathrm{Ca}, \mathrm{Mg}\right.$, and $\mathrm{Mn}$ availability), fruit quality (wet fruit weight, fruit skin, fruit flesh, and seeds), levels of leaf chemical properties (N, P, K, Ca, Mg, Fe, Cu, Zn, and Mn).

\subsection{Soil Sampling and Analysis}

Soil samples were taken using a stainless steel auger at a depth of $0-30 \mathrm{~cm}$. Each composite soil sample consisted of 5 sub-samples taken randomly from 4 cardinal directions around the root zone of the sample plants. Soil samples were air-dried, pulverized, ground and sieved through a $2 \mathrm{~mm}$ diameter sieve, and then stored for analysis. The fine soil with a diameter of 2 $\mathrm{mm}$ was then ground so that it could pass a 0.5 $\mathrm{mm}$ sieve for organic carbon analysis. Parameters of soil chemical properties observed were $\mathrm{pH} \quad \mathrm{H}_{2} \mathrm{O}$ (1:5), $\mathrm{Ca}$ and $\mathrm{Mg}$ were interchangeable, and $\mathrm{Mn}$ availability.

Soil $\mathrm{pH}$ analysis was carried out by diluting it in a ratio of $1: 5(\mathrm{w} / \mathrm{v})$, shaking with a shaker for 30 minutes, and measuring with a $\mathrm{pH}$ meter that had been calibrated with $\mathrm{pH}$ buffers of 7.0 and 4.0. The exchangeable $\mathrm{Ca}$ and $\mathrm{Mg}$ were analyzed by $\mathrm{NH}_{4} \mathrm{OAc} 1 M$ method (buffer $\mathrm{pH}$ 7.0) measured by atomic absorption spectrophotometer. $\mathrm{Mn}$ was analyzed by the dithionite-citrate method and measured by atomic absorption spectrophotometer.

\subsection{Analysis of Leaf and Fruit Skin Samples}

Leaf and fruit skin samples were collected from the same location where soil and fruit samples were obtained. The terminal leaves that were fully developed on the outside in the 4 cardinal directions were taken as many as 12 leaves for each tree. Fruit skin samples were taken when the fruit was physiologically ripe (harvest index 4). Prior to stripping, it was cleaned with ionized water and cut into pieces of $2-3 \mathrm{~cm}$ in size. Samples of leaves and fruit skin that have been cleaned were dried at room temperature and oven at $70^{\circ} \mathrm{C}$ (24 hours) until their weight was stable. After the leaf and fruit skin samples were dried, the samples were ground and stored for analysis.

Leaf and fruit skin samples were analyzed for $\mathrm{K}$, $\mathrm{Ca}, \mathrm{Mg}$, and $\mathrm{Mn}$ nutrients. Samples of leaves and fruit skin that had been ground were extracted by wet ashing with a mixture of concentrated acids $\mathrm{HNO}_{3}$ and $\mathrm{HClO}_{4}$. Measurement of $\mathrm{K}, \mathrm{Ca}$, and $\mathrm{Mg}$ was carried out with $1 \mathrm{ml}$ of extract plus $9 \mathrm{ml}$ of $25 \%$ lanthanum solution and measured by atomic absorption spectrophotometer. $\mathrm{Mn}$ was measured directly from the extract with an atomic absorption spectrophotometer [17].

The critical level of $\mathrm{Mn}$ in leaves and soil was determined based on the relationship of $\mathrm{Mn}$ concentration in the leaves and soil with the weight of mangosteen fruit. In the graph, vertical and horizontal lines are drawn, the two lines are shifted to the right and left, up and down so that the point in the four-part are relatively equal $[18,19]$.

\section{RESULTS AND DISCUSSION}

\subsection{Soil Chemical Properties}

The result of soil analysis from six sites showed that Karacak and Barengkok were categorized as acid soil with soil pH 4.81 and 4.31 respectively. Meanwhile, Simalangang, Banja Loweh, Belimbing, and Selamadek were classified as slightly acid as 5.61, 5.70, 5.87, and 5.92, respectively (Table 1 ).

Soil available $\mathrm{Ca}$ and $\mathrm{Mg}$ were ranged from 5.09 to 12.29 and 0.46 to $2.26 \mathrm{cmol}(+) \mathrm{kg}^{-1}$ respectively, and both were categorized as low to high [17],. The concentration of exchangeable $\mathrm{Ca}$ and $\mathrm{Mg}$ exchangeable could affect the soil $\mathrm{pH}$ (Fig. 1). The increasing of $\mathrm{Ca}$ concentration in soil from 3.59 to $16.18 \mathrm{cmol}_{(+)} \mathrm{kg}^{-1}$ could increase soil pH from 4.10 to 6.20 . The increase of soil $\mathrm{pH}$ might be due to the increase of exchangeable $\mathrm{Ca}$ in the soil as $\mathrm{Ca}$ reacts with $\mathrm{H}_{2} \mathrm{O}$ and donates $\mathrm{OH}^{-}$and decrease the ion $\mathrm{H}^{+}$ concentration in soil solution. Increasing the $\mathrm{Mg}$ concentration in soil from 0.29 to $2.18 \mathrm{cmol}_{(+)} \mathrm{kg}^{-1}$ affected the increase of soil pH from 4.09 to 6.20 .

Soil available $\mathrm{Mn}$ ranged from 18.89 to 33.63 ppm and was categorized as high. According to 
Fageria et al. [2], as the $\mathrm{pH}$ decreases at low soil $\mathrm{pH}(<5.2), \mathrm{Mn}$ is mobilized from various fractions and increases $\mathrm{Mn}$ concentration in soil solution and its availability. Soil pH has a dominant effect on solubility, therefore, the availability and potential phytotoxicity of ions (nutrients and toxic elements) [20]. Mn excess results in a sharp decrease in shoot height, biomass accumulation, and total leaf area of a woody species Populuscathayana [21].

The present study showed that increasing soil $\mathrm{pH}$ from 4.1 to 6.4 was followed by the decreasing of soil available $\mathrm{Mn}$ as 35.8 to $16 \mathrm{ppm}$ (Fig. 2). Previous research found that Mn toxicity is a limiting factor for plant growth especially in acid soil with soil pH below 5.6 and low availability of $\mathrm{Ca}$ and $\mathrm{Mg}$. Increasing soil pH will be followed by the decreasing of soil available Mn. In general, increasing one unit of $\mathrm{pH}$ could decreased $\mathrm{Mn}$ concentration by 100 -fold $[1,22]$.

There was a positive correlation between $\mathrm{Ca}$ and soil $\mathrm{pH}$ and $\mathrm{Mg}$ and soil $\mathrm{pH}$ with $\mathrm{R}^{2}$ as 0.72 and 0.58 , respectively (Fig. 1). Meanwhile, a correlation on $\mathrm{Mn}$ with soil $\mathrm{pH}, \mathrm{Mn}$ and $\mathrm{Ca}$, and $\mathrm{Mn}$ with $\mathrm{Mg}$ showed a negative correlation with $R^{2}$ values as $0.57,0.46$, and 0.36 respectively (Fig 2). Mn toxicity may become a limiting factor for crop production when mostly available in $\mathrm{Mn}^{2+}$ form. $\mathrm{Mn}^{2+}$ is highly soluble and is the thermodynamically most stable form in soils at low $\mathrm{pH}$.

The concentration of $\mathrm{Mn}^{2+}$ in the soil solution can vary markedly, depending on the soil solution $\mathrm{pH}$. Acidification of the rhizosphere by exudation of $\mathrm{H}^{+}$or organic acids increases the availability of $\mathrm{Mn}^{2+}$ for accumulation into the cell. However, when soils $\mathrm{pH}$ decreases (< $\mathrm{pH} 5.5), \mathrm{Mn}^{2+}$ toxicity could be a critical limiting factor to plant growth [1].

The increasing of Mn availability in the soil will be followed by the decrease of $\mathrm{Ca}$ and $\mathrm{Mg}$ availability at several mangosteens productions centers (Fig. 2). Mn concentration decreased from 35.8 to $15 \mathrm{ppm}$ and followed with the increase of $\mathrm{Ca}$ from 3.59 to $17.8 \mathrm{cmol}_{(+)} \mathrm{kg}^{-1}$, or the $\mathrm{Mn}$ content decreased by $1.46 \mathrm{ppm}$ when $\mathrm{Ca}$ increased by $1.00 \mathrm{cmol}_{(+)} \mathrm{kg}^{-1}$. Meanwhile the decreasing of $\mathrm{Mn}$ concentration from 32.6 to 17 ppm and $\mathrm{Mg}$ concentration increased from 0.2 to $2.58 \mathrm{cmol}_{(+)} \mathrm{kg}^{-1}$, and the decreasing of $\mathrm{Mn}$ concentration as $6.55 \mathrm{ppm}$ followed with increasing $\mathrm{Mg}$ concentration by $1.00 \mathrm{cmol}_{(+)} \mathrm{kg}^{-1}$. This condition occurred in calcareous soil. As

Table 1. Soil chemical properties from 60 soil samples collected from each site

\begin{tabular}{lllll}
\hline Location & $\mathbf{p H ~} \mathbf{H}_{2} \mathbf{O}$ & $\mathbf{C a}\left(\mathbf{c m o l}_{(+)} \mathbf{k g}^{-1}\right)$ & $\mathbf{M g}(\mathbf{c m o l}$ \\
\hline Simalanggang & $5.61 \pm 0.45$ & $9.58 \pm 3.86$ & $\mathbf{M n}(\mathbf{p p m})$ \\
Banja Laweh & $5.70 \pm 0.25$ & $11.79 \pm 1.01$ & $1.35 \pm 0.34$ & $18.89 \pm 2.00$ \\
Karacak & $4.81 \pm 0.25$ & $5.92 \pm 1.60$ & $1.02 \pm 0.25$ & $22.02 \pm 2.04$ \\
Barengkok & $4.31 \pm 0.22$ & $5.09 \pm 1.41$ & $0.58 \pm 0.16$ & $31.91 \pm 4.45$ \\
Belimbing & $5.87 \pm 0.18$ & $11.03 \pm 1.59$ & $0.46 \pm 0.26$ & $33.63 \pm 3.82$ \\
Selamadeg & $5.92 \pm 0.44$ & $12.29 \pm 4.77$ & $2.26 \pm 0.53$ & $24.81 \pm 2.94$ \\
\hline \multicolumn{5}{c}{ Note: data are means + standard error }
\end{tabular}

Note: data are means \pm standard error
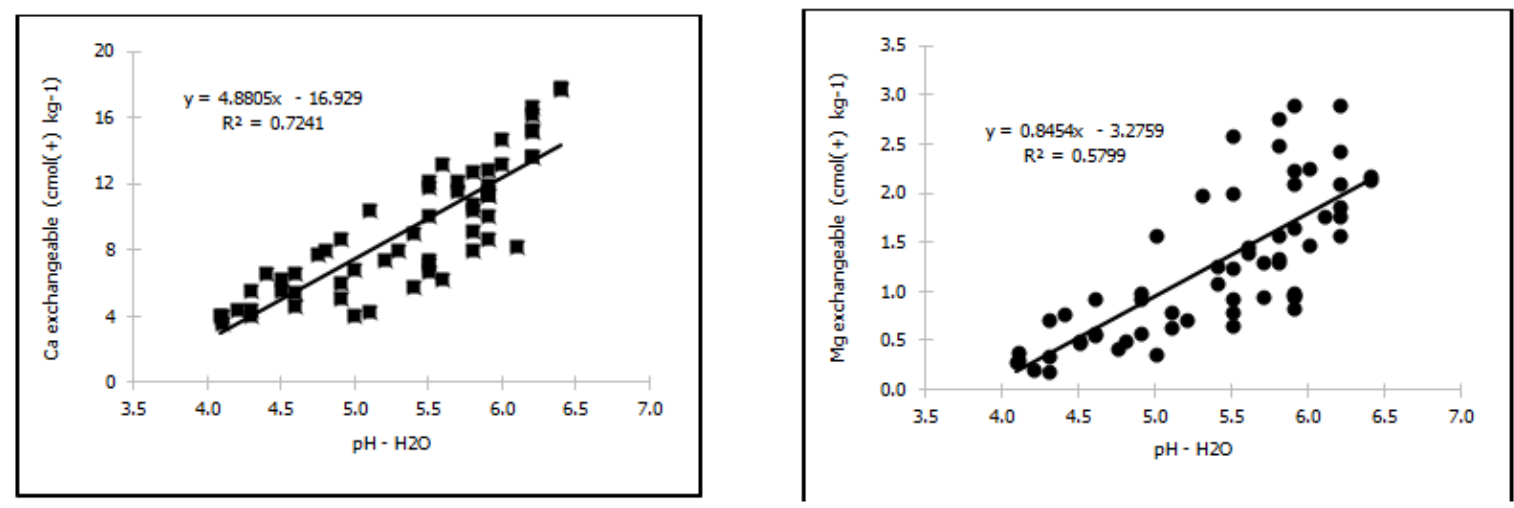

Fig. 1. Relationship between soil pH and soil nutrient concentration of $\mathrm{Ca}$ and exchangeable $\mathrm{Mg}$ in the soil 
stated by Rutkowska et al. [23], liming could decrease $\mathrm{Mn}$ and $\mathrm{Zn}$ concentration in the soil extracted by $1 \mathrm{~mol} / \mathrm{l} \mathrm{HCl}$. Recently studied by Martias et al. [24] showed that application of submicron dolomite more than $120 \mathrm{~g} /$ tree decreased Mn concentration in mangosteen leaves.

Mn deficiency could be a serious nutrient disorder in a plant that grows in dry, and calcareous soils, as well as in soils with high organic matter content, where the bio-availability of $\mathrm{Mn}$ could reduce below the necessary amount for supporting plant growth [25].

\subsection{Relationship of Soil Available Mn with Mn in Leaves and the Quality of Fruits}

To enhance mangosteen quality, $\mathrm{Mn}$ is needed at a certain level. However, under abundant amounts, Mn could decline the quality of fruit (Fig. 3). The present study showed that the critical limit of $\mathrm{Mn}$ in the soil affected fruit quality in several parameters, namely the weight of fruit and skin, fruit diameter, and mangosteen rind thickness. The critical level of soil available Mn from this study ranges from 22 to $24 \mathrm{ppm}$ (Fig. $3)$.
Manganese is a micronutrient that is relatively easily absorbed by the roots of plants, and its absorption even exceeded the requirement. As soil availability, $\mathrm{Mn}$ increases, $\mathrm{Mn}$ concentration in leaves increases as well, and this proved that these ions are relatively easily absorbed by mangosteen roots and translocated to leaf tissue. This present study showed that the lowest $\mathrm{Mn}$ level was 134 ppm and the highest was 1131 ppm in mangosteen leaf tissue (Fig. 4). There is a linear relationship with $R^{2}=0.76$ between soil available $\mathrm{Mn}$ and leaves, indicates that the increasing soil available $\mathrm{Mn}$ follows by the increase in $\mathrm{Mn}$ concentration in leaves. This finding on Mn behavior in this present study is in agreement with Blamey et al. [26].

Previous results showed that the increasing of $\mathrm{Mn}$ concentration from 0.5 to $30 \mu \mathrm{M} \mathrm{Mn}$ in solution, increased $\mathrm{Mn}$ concentration in cowpea and soybean leaf tissues from 160 to 1100 $\mathrm{mg} \cdot \mathrm{kg}^{-1}$; the corresponding increase at $400 \mu \mathrm{M}$ $\mathrm{Mn}$ was from 90 to $6400 \mathrm{mg} \mathrm{kg}^{-1}$ in sunflower and from 310 to12 $000 \mathrm{mg} \cdot \mathrm{kg}^{-1}$ in white lupin $[10,26]$. Fernando et al. [27] was the first to show that $\mathrm{Mn}$ is evenly distributed in leaf photosynthetic and nonphotosynthetic tissues.
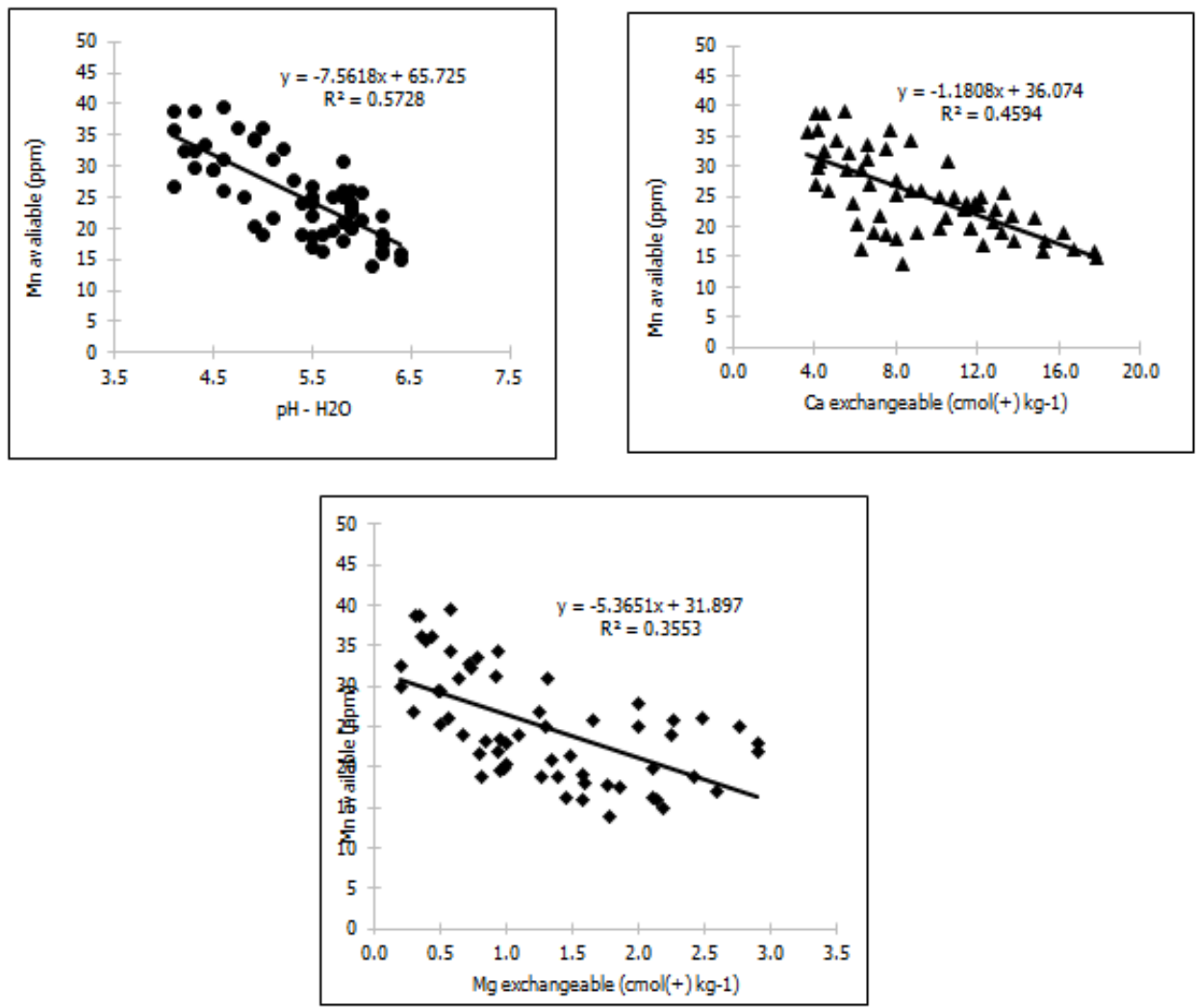

Fig. 2. Relationship between $\mathrm{Mn}$ available and soil $\mathrm{pH}$, Ca concentration and exchangeable $\mathrm{Mg}$ 

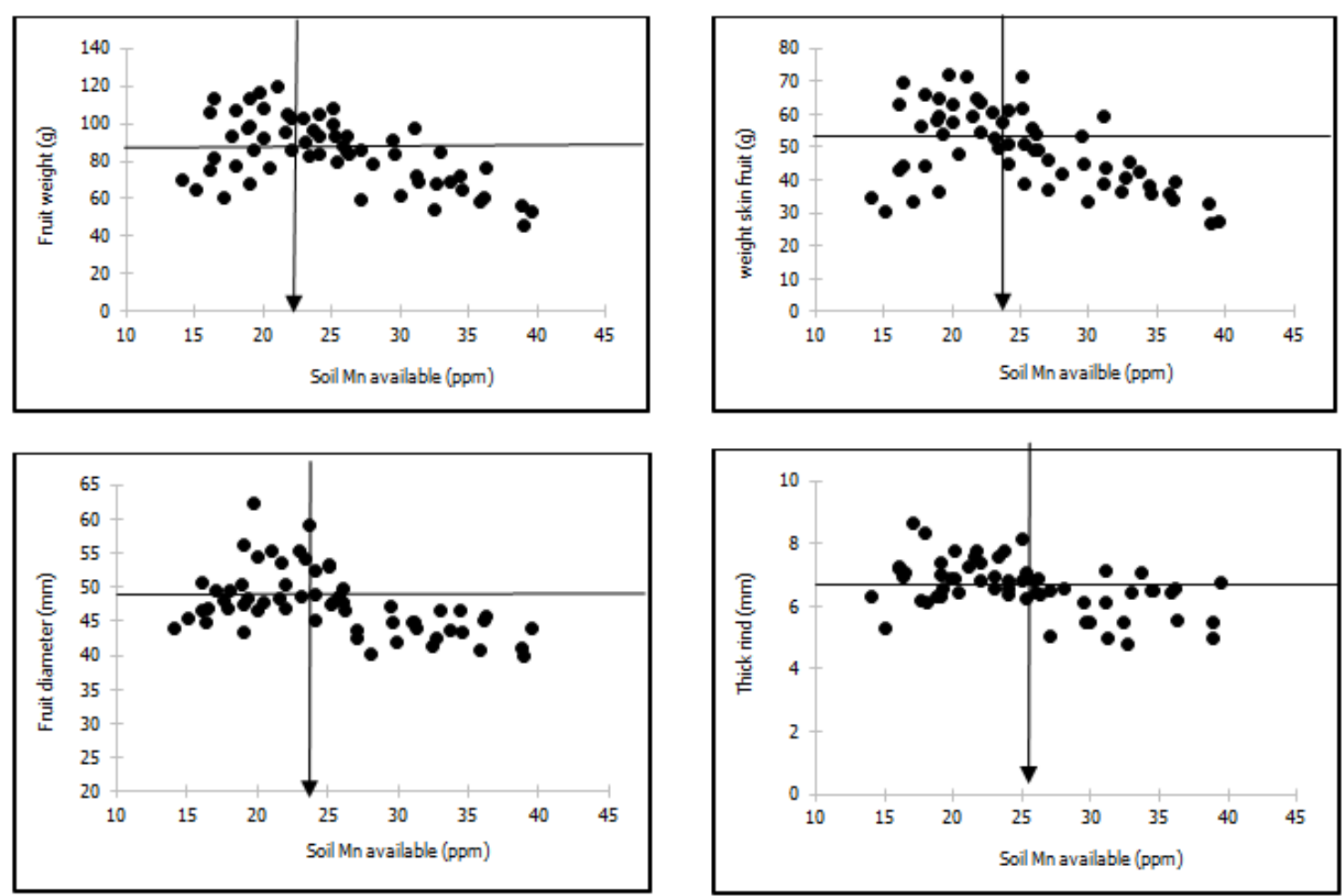

Fig. 3. The critical level of soil available Mn for fruit weight, skin weight, fruit diameter, and mangosteen rind thickness

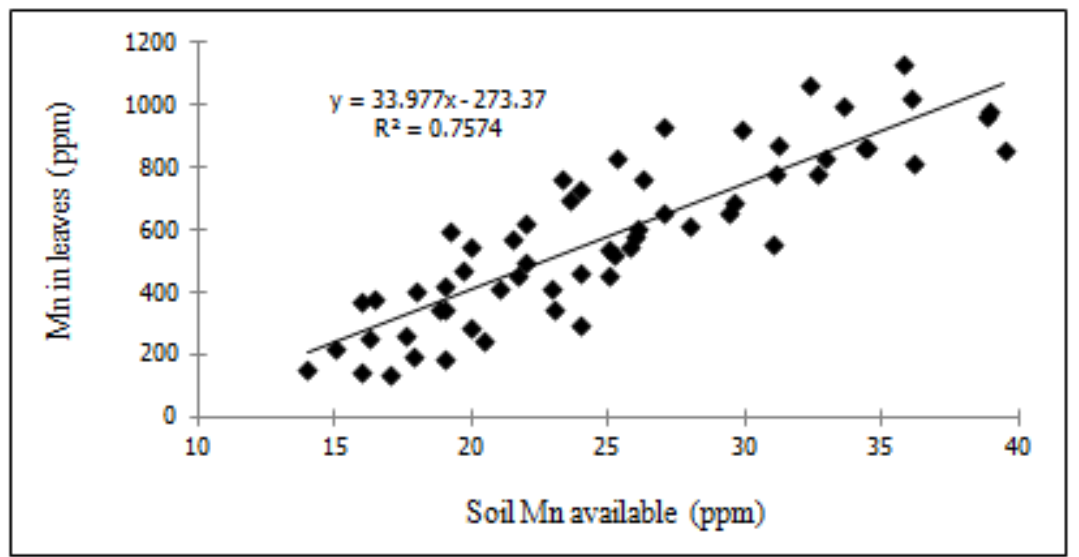

Fig. 4. The relationship of $\mathrm{Mn}$ concentration in soil and mangosteen leaf at study sites

The regression analysis showed a quadratic relationship between the leaf nutrient content and fruit weight (Fig. 5). These results revealed that $\mathrm{Mn}$ is required in mangosteen growth as seen in the relationship between the leaf $\mathrm{Mn}$ and fruit production. However, the excessive absorption of $\mathrm{Mn}$ by the plants is potentially toxic and this circumstance leads to a decrease in the weight of the mangosteen fruit (Fig. 5). The relationship of leaf $\mathrm{Mn}$ concentration with mangosteen fruit weight shows the content of $\mathrm{Mn}$
$317 \mathrm{ppm}$ to $432 \mathrm{ppm}$ is the level of Mn optimum to produce fruit weight mangosteen.

The symptoms of $\mathrm{Mn}$ toxicity vary widely among plant species, with chlorotic leaves and necrotic spots as the most common symptoms [28]. Decreased photosynthesis reduces the weight of mangosteen fruit. The relationship between the $\mathrm{Mn}$ concentration in the leaves and the mangosteen fruit weight is quadratic. Mn levels in the leaves $<400 \mathrm{ppm}$ could increase the weight 
of the mangosteen fruit, and however $>400 \mathrm{ppm}$ reduces the weight of the mangosteen fruit. Thus, it can be concluded that the critical limit of $\mathrm{Mn}$ nutrients in mangosteen leaves is $425 \mathrm{ppm}$. As $\mathrm{Mn}$ concentration in leaves increased from 134 to $400 \mathrm{ppm}$, the mangosteen fruit weight increase from 61.40 to $120.27 \mathrm{~g}$ as well. However, the increase of $\mathrm{Mn}$ concentration in leaves above $400 \mathrm{ppm}$ caused the decrease of fruit weight from 117.27 to $46.10 \mathrm{~g}$. The lowest mangosteen fruit weight was $46.10 \mathrm{~g}$ with $\mathrm{Mn}$ concentration in leaves was reached $976 \mathrm{ppm}$.

Manganese deficiency often occurs as a latent disorder without clear visual symptoms. Latent $\mathrm{Mn}$ deficiency substantially increases transpirationand decreases the water use efficiency (WUE) in barley plants [28]. One of the consequences of Mn deficiency in plants is an impaired growth, leading to a decrease in biomass [29]. Mn deficiency caused severe yield and quality reductions in crops [30].

The range of $\mathrm{Mn}$ concentration ins of leaves differs greatly among species as $30-500 \mathrm{mgkg}^{-1}$ $\mathrm{Mn}$ dry weight. Nonetheless, when it is present in excessive amounts, it is extremely toxic to plant cells [31]. At higher light intensities, Mn toxicity has been causally linked to inhibition of photosynthesis and ensuing oxidative stress [32].

\subsection{Interaction between $\mathrm{Mn}$ with $\mathrm{K}, \mathrm{Ca}$, and $\mathrm{Mg}$ in Leaves}

The concentration of $\mathrm{Ca}, \mathrm{Mg}$, and $\mathrm{K}$ in the leaves have the effect of increasing the $\mathrm{Mn}$ concentration in the leaves. The result showed that at above $400 \mathrm{ppm}$ of $\mathrm{Mn}$ in leaves, the concentration of $\mathrm{Ca}, \mathrm{Mg}$, and $\mathrm{K}$ in the leaves decreased (Fig. 6). The Mn content in the leaves began to decrease when $\mathrm{Ca}, \mathrm{Mg}$, and $\mathrm{K}$ reached $2.2,0.45$, and $1.83 \%$ respectively. This result showed that the absorption of $\mathrm{Mn}$ in high concentrations could disrupt the absorption of $\mathrm{Ca}, \mathrm{Mg}$, and $\mathrm{K}$.

The excess $\mathrm{Mn}$ interferes with the absorption, translocation, and utilization of mineral elements such as $\mathrm{Ca}, \mathrm{Mg}$, and $\mathrm{Fe}$. Potassium, $\mathrm{Ca}$, and $\mathrm{Mg}$ is needed for the development of mangosteen fruit. Excessive Mn can prevent the uptake and translocation of other essential elements such as $\mathrm{Ca}, \mathrm{Mg}, \mathrm{Fe}$, and $\mathrm{P}[10,11]$. The level of $\mathrm{K}, \mathrm{Ca}$ and $\mathrm{Mg}$ had a positive and significant correlation with fruit weight, skin weight, and aryl weight, seed weight, and mangosteen fruit diameter (Tabel 2). This present result proved that these nutrients take a role in improving the quality of the mangosteen.

The correlation between soil and leaf $\mathrm{Mn}$ was negative and significantly related to fruit weight, rind weight, aril weight, seed weight, fruit diameter, and mangosteen rind thickness. This means that increasing $\mathrm{Mn}$ concentration in soil and leaves at certain levels could give have a negative impact on mangosteen quality. Thus, it is necessary to maintain a sufficient amount of $\mathrm{Mn}$ concentration in the soil and leaves. The nutrient efficient plants play an important role in increasing crop yields per unit area as well as improve health and quality of human life [2].

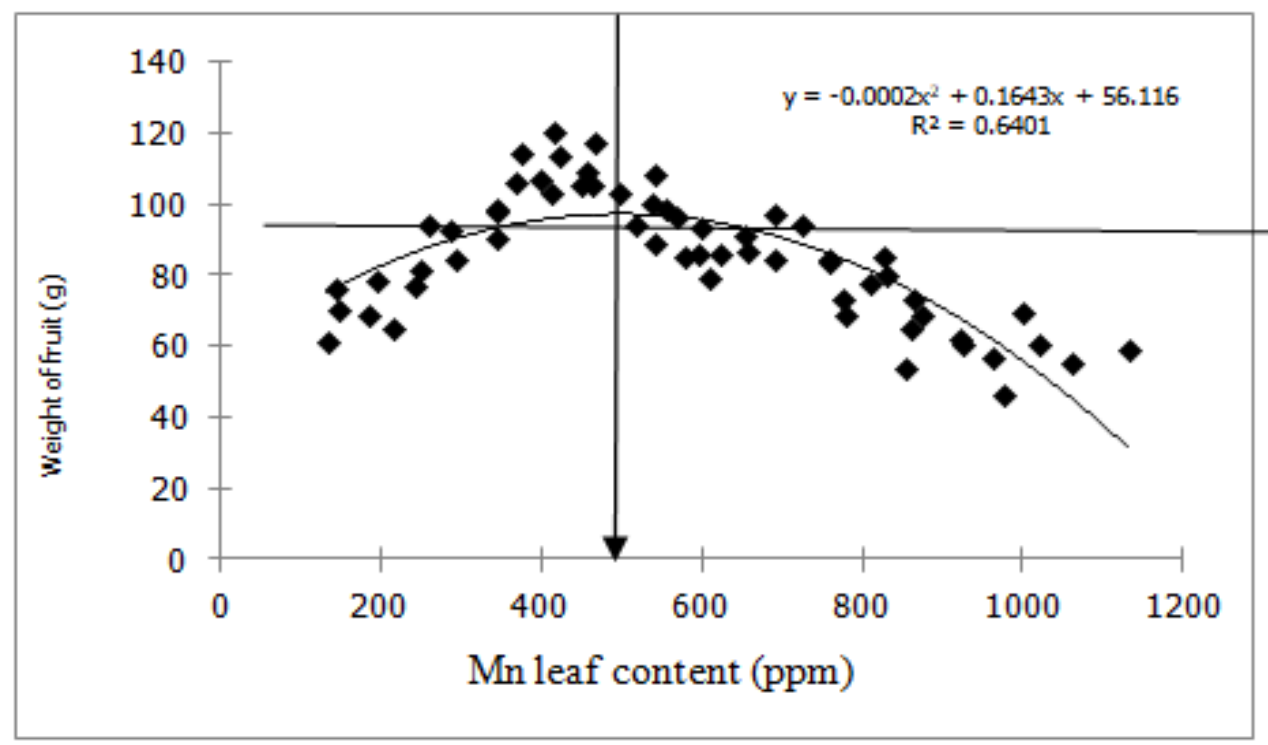

Fig. 5. Relationship of Mn leaf levels with mangosteen weight in study sites 
Table 2. Correlation of various types of nutrient to the physical quality components of the mangosteen fruit, $\mathrm{n}=100$

\begin{tabular}{|c|c|c|c|c|c|c|c|}
\hline $\begin{array}{l}\text { Components of } \\
\text { mangosteen fruit }\end{array}$ & $\begin{array}{l}\text { Exchangeable } \\
\mathrm{Ca}\end{array}$ & $\begin{array}{l}\text { Exchangeable } \\
\text { Mg }\end{array}$ & $\begin{array}{l}\text { Available } \\
\text { Mn- }\end{array}$ & Leaf-K & $\begin{array}{l}\text { Leaf- } \\
\mathrm{Ca}\end{array}$ & $\begin{array}{l}\text { Leaf- } \\
\text { Mg }\end{array}$ & $\begin{array}{l}\text { Leaf- } \\
\text { Mn }\end{array}$ \\
\hline Fruit weight & 0.431 & 0.322 & -0.552 & $0.613^{\prime \prime}$ & $0.750^{\star \star}$ & $0.842^{\star \star}$ & $-0.476^{\star *}$ \\
\hline Fruit skin weight & $0.383^{\star *}$ & $0.289^{*}$ & $-0.511^{\star *}$ & $0.554^{\star \star}$ & $0.695^{\star *}$ & $0.803^{\star *}$ & $-0.415^{\star *}$ \\
\hline Aryl weight & $0.421^{* *}$ & $0.304^{*}$ & $-0.517^{\star *}$ & $0.584^{* *}$ & $0.702^{\star *}$ & $0.762^{\star \star}$ & $-0.480^{* *}$ \\
\hline Seed weight & $0.258^{*}$ & $0.270^{*}$ & -0.245 & $0.536^{\star \star}$ & $0.556^{\star *}$ & $0.552^{* *}$ & -0.243 \\
\hline Fruit diameter & $0.458^{\star *}$ & 0.147 & $-0.487^{\star x}$ & $0.633^{* x}$ & $0.538^{* *}$ & $0.684^{* *}$ & $-0.354^{* *}$ \\
\hline Thick rind & $0.540^{* *}$ & $0.422^{* *}$ & $-0.456^{\star *}$ & $0.461^{\star *}$ & $0.325^{\star}$ & $0.408^{\star *}$ & $-0.460^{* *}$ \\
\hline
\end{tabular}

${ }^{1}$ Pearson correlation coefficient followed by ${ }^{*},{ }^{* *}$ are significantly correlated at $P<0.05$ and 0.01 , respectively.
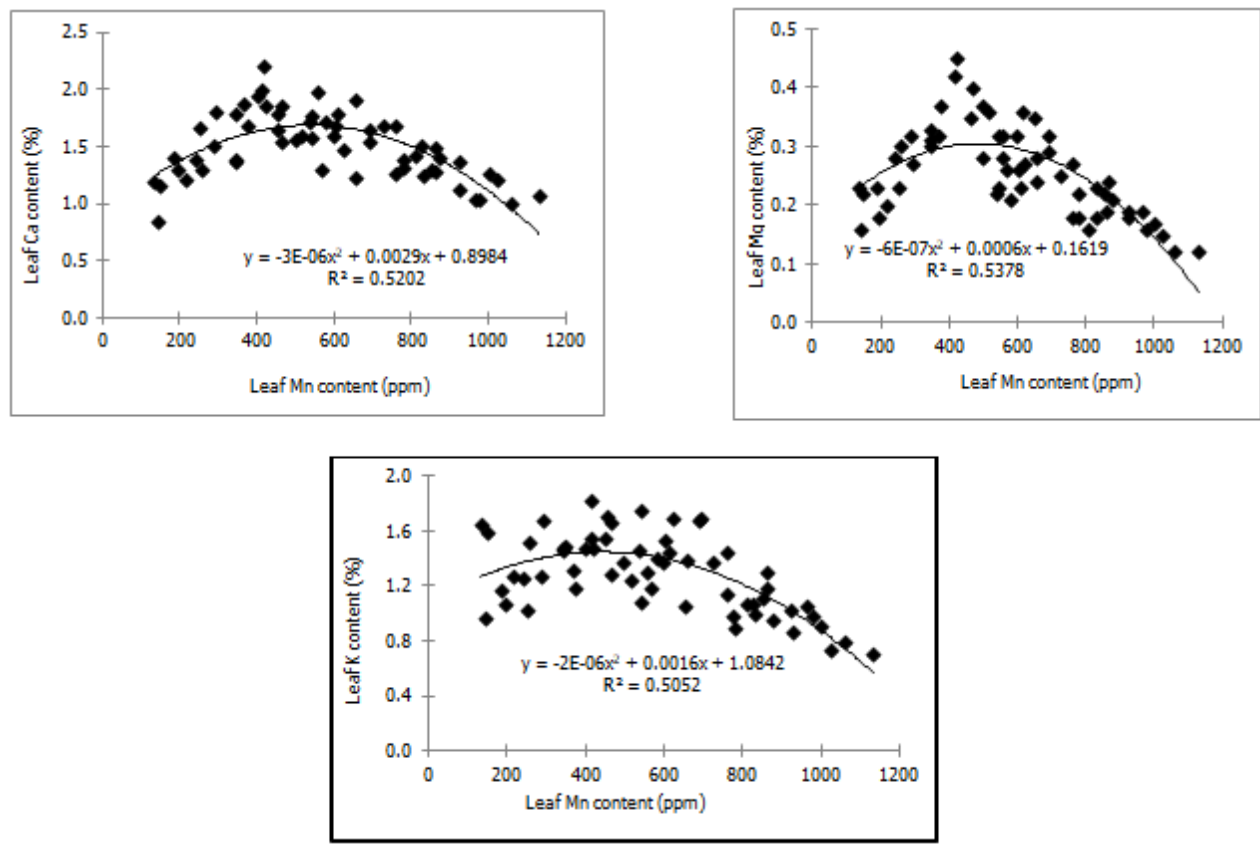

Fig. 6. Effect of $\mathrm{Ca}, \mathrm{Mg}$, and $\mathrm{K}$ on $\mathrm{Mn}$ content in mangosteen leaves 


\section{CONCLUSIONS}

The available $\mathrm{Mn}$ in the soil is negatively affected by $\mathrm{pH}, \mathrm{Ca}$, and $\mathrm{Mg}$ with $\mathrm{R}^{2} 0.57,0.46$, and 0.36 , respectively. The concentration of $\mathrm{Mg}, \mathrm{Ca}$, and $\mathrm{K}$ in leaves increased when $\mathrm{Mn}$ concentration was below $400 \mathrm{ppm}$, and decreased when $\mathrm{Mn}$ is more than $400 \mathrm{ppm}$. There was a negative correlation between $\mathrm{Mn}$ in the soil and leaves with mangosteen fruit quality. The critical value of $\mathrm{Mn}$ in mangosteen leaves is around $425 \mathrm{ppm}$, while in the soil it ranges from 22 to $24 \mathrm{ppm}$.

\section{ACKNOWLEDGEMENTS}

Thanks to the Indonesian Agency for Agricultural Research and Development by Indonesia Center for Horticulture Research and Development for the research funding.

\section{COMPETING INTERESTS}

Authors have declared that no competing interests exist.

\section{REFERENCES}

1. Marschner H. Mineral nutrition of higher plants, $2^{\text {nd }}$ edition. London: Academic Press;1995.

2. Fageria $\mathrm{N}$, Baligar $\mathrm{V}$, Clark R. Micronutrients in crop production. Adv. Agron. 2002;77:185-268.

3. Buchanan B, Grusen W, Jones R. Biochemistry and molecular biology of plants. American Society. of Plant Physiologists Maryland. 2000;1367.

4. Alejandro S, Holler S, Meier B, Peiter G. Review. Manganese in plant: From acquisition to subcelluler allocation. Frontier in Plant Science. 2020;11: 300.

DOI: $10.3389 /$ fpls.2020.00300.

5. Schmidt SB, Jensen P E, and HustedS. Manganese deficiency in plants:The impact on photosystem II. Trends Plant Sci. 2016;21:622-632.

DOI: 10.1016/j.tplants.2016.03.001.

6. Lanquar V, Ramos MS, Lelièvre $F$, Barbier-Brygoo $\mathrm{H}$, KriegerLiszkay $\mathrm{A}$, Krämer U, Thomine S. Export of vacuolar manganese by AtNRAMP3 and AtNRAMP4 is required for optimal photosynthesis and growth under manganese defciency. Plant Physiology. 2010;152:1986-1999.

7. Viégas IJM, RAM Cordeiro, GM de Almeida, DAS Silva, BC da Silva, RS Okumura, MLJ da Silva, SP da Silva, and JMN de Freistas. Growth and visual symptoms of nutrients deficiency in mangosteents (Garciniamangostana L). American Journal of Plant Science. 2018;9:1014-1028

8. Yao Y, Xu G, Mou D, Wang J, and Ma, J. Subcellular $\mathrm{Mn}$ compartation, anatomic and biochemical changes of two grape varieties in response to excess manganese. Chemosphere 2012; 89: 150157.

DOI: 10.1016/j.chemosphere.2012.05.030.

9. Alam S, Akiha F, Kamei, S, Huq S M I, and Kawai S. Mechanism ofpotassium alleviation of manganese phytotoxicity in barley. J. Plant Nutr. 2005;28:889901.

DOI:10.1081/pln-200055572.

10. Blamey $F \quad P$ C, Hernandez-Soriano $M$, Cheng, M, Tang C, PatersonD, LombiE. Synchrotron-based techniques shed light on mechanisms ofplant sensitivity and tolerance to high manganese in the root environment.Plant

Physiol. 2015;169:2006-2020.

DOI: 10.1104/pp.15.00726.

11. Lešková A, Giehl RFH, Hartmann A, Fargašová $A$, and von WirénN. Heavy metals induce iron deficiency responses at different hierarchic and regulatory levels. Plant Physiol. 2017;174: 1648-1668.

DOI: 10.1104/pp.16.01916.

12. Subrahmanyam, D, and Rathore, V S. Influence of manganese toxicity on photosynthesis in ricebean (Vigna umbellata) seedlings. Photosynthetica. 2001;38:449-453.

13. Amao $\mathrm{Y}$, and Ohashi $A$. Effect of $M n$ ion on the visible light induced water oxidation activity of photosynthetic organ grana from spinach. Catal. Commun. 2008;10:217220.

DOI: 10.1016/j.catcom.2008.08.022.

14. Fecht-Christoffers $M M$, Führs $H$, Braun $\mathrm{HP}$, and Horst WJ. The role of hydrogen peroxide-producing and hydrogen peroxide-consuming peroxidases in the leaf apoplast of cowpea in manganese 
tolerance. Plant Physiol. 2006; 140: 14511463.

DOI: 10.1104/pp.105.070474.

15. Fernando D R, Bakkaus, E J, Perrier N, Baker A J, Woodrow I E, Batianoff, G N. 2006. Manganese accumulation in the leaf mesophyll of fourtree species: A PIXE/EDAX localization study. New Phytol.2006;171:751-758.

DOI:10.1111/j.1469-8137.2006.01783.x

16. Palapol YS ,Ketsa S, Stevenson D, Cooney JM, Allan AC, Ferguson IB. Colour development and quality of mangosteen (Garcinia mangostana L.) fruit during ripening and after harvest. Postharvest Biology and Technology. 2009;51: 349353.

DOI:10.1016/j.postharvbio.2008.08.003

17. Eviati and Sulaeman. Petunjuk Teknis. Edisi 2. Analisis Kimia Tanah, Tanaman, Air, dan Pupuk (in Bahasa), Balai Penelitian Tanah, Balai Besar Litbang Sumber Daya LahanPertanian. Badan Penelitian dan Pengembangan Pertanian. Departemen Pertanian; 2009.

18. Banerjee A, Chattopadhyay GN, Boyd CE. 2009. Determination of critical limits of soil nutrients for use in optimizing fertilizer rates for fish ponds in red, lateritic soil zones. Aquacultural Engineering. 2009; 40:144-148

19. Neto, de. AJL. Neves JC.L., Martinez HEP, Sousa JS, Fenandes LV. . Establishment of critical nutrient levels in soil and plant for eucalyptus. Rev Bras Cienc Solo. 2020;44:e0190150. Rev Bras Cienc Solo

20. Clark, RB, Baligar VC. 2000. Acidic and alkalinesoil constraints on plant mineral nutrition. In: R. E.Wilkinson (ed.) PlantEnvironment Interactions.Marcel Dekker Inc, New York. 2000;133-177.

21. Lei $Y$, Korpelainen H, Li C. Physiological and biochemical responses to high $\mathrm{Mn}$ concentrations in two contrasting Populus cathayana Chemosphere.2007;68:686-694. DOI:10.1016/j.chemosphere.2007.01.066.

22. Hue NV, Silvio Vega, Silva JA. Manganese Toxicity in a Hawaiian Oxisol Affected by Soil $\mathrm{pH}$ and Organic Amendments. Soil Sci. Soc. Am. J. 2001;65:153-160.

23. Rutkowska B, Szulc W, Sosulski T, Stępień W. 2014. Soil micronutrient availability to crops affected by long-term inorganic and organic fertilizer applications. Plant Soil Environ. 2014; 60(5):198-203.

24. Martias, SpartaA, Hendri, Fatria D, Marlina $L$ and Mansyah E. The potency of submicron dolomite in reducing yellow latex contamination in mangosteen fruits. 1st International Conference on Sustainable Tropical Land Management. IOP Conf. Series: Earth and Environmental Science. $2021 ; 648012139$.

DOI:10.1088/1755-1315/648/1/012139.

25. Broadley M, Brown P, Cakmak I, Rengel Z, and Zhao F. Functionn of nutrients: micronutrients," in Marschner's Mineral Nutrition of Higher Plants, 3rd Edn, ed. P. Marschner (Oxford: Elsevier). 2012;191249.

26. Blamey FPC, McKenna BA, Li C, Cheng $M$, Tang $C$, Jiang $H$, Howard $D L$, Paterson DJ, Kappen P, Wang P, Menzies NW and Kopittke PM. Manganese distribution and speciation help to explain the effectsof silicate and phosphate on manganese toxicity in four crop species. New Phytologist. 2018;217:1146-1160.

DOI: 10.1111/nph.14878.

27. Fernando DR, Marshall AT, Gouget B, Carriere M, Collins RN, WoodrowIE, Baker AJ.Novel pattern of foliar metal distribution in a manganese hyperaccumulator. Funct Plant Biol. 2008;35: 193-200.

28. Millaleo R, Reyes-Diaz M, Ivanov A G, Mora M L, and Alberdi M. Manganese as essential and toxic element for plants: transport, accumulation and resistance mechanisms. J. Soil Sci. Plant Nutr. 2010; 10: 470-481.doi: 10.4067/s07189516201000020000829. Hebbern CA., Laursen KH, Ladegaard AH, Schmidt SB, Pedas P, Bruhn D. Latent manganese deficiency increases transpirationin barley (Hordeum vulgare). Physiol. Plant. 2009;135:307-316.

DOI: 10.1111/j.1399-3054.2008.01188.

29. Pedas P, Hebbern, CA., Schjoerring, J.j K., Holm, P. E and HustedS. Differential capacity for high-affinity manganese uptake contributes todifferences between barley genotypes in tolerance to low manganese availability. Plant Physiol. 2005;139:1411-1420.

DOI: 10.1104/pp.105.067561. 
30. Yang XE, Chen WR, Feng Y. Improving human micronutrient nutrition through biofortification in the soil-plant system: China as a case study. Environ Geochem Health. 2007;29:413-428.

31. Migocka M and Klobus $G$. The properties of the $\mathrm{Mn}, \mathrm{Ni}$ and $\mathrm{Pb}$ transport operating at plasma membranes of cucumber roots.
Physiologia Plantarum. 2007;129:578587.

DOI: 10.1111/j.1399-3054.2006.00842.x.

32. Andresen E, Peiter E and Küpper H. Trace metal metabolism in plants. J. Exp. Bot. 2018; 69: 909-954. DOI: $10.1093 / j \times b / e r x 465$.

(c) 2021 Martias et al.; This is an Open Access article distributed under the terms of the Creative Commons Attribution License (http://creativecommons.org/licenses/by/4.0), which permits unrestricted use, distribution, and reproduction in any medium, provided the original work is properly cited. 